\title{
Faktor-Faktor yang Berhubungan dengan Penggunaan Complementary And Alternative Medicine (CAM) pada Pasien Diabetes Melitus di Puskesmas Poasia Kota Kendari
}

Risqi Wahyu Susanti ${ }^{1}$, Diah Indriastuti ${ }^{2}$

\begin{abstract}
Abstrak
Pengetahuan masyarakat mengenai pengobatan penderita DM tak lepas dari saran penggunaan terapi komplemeter obat herbal, yang tidak jarang menjadi alternatif pemecahan masalah ketika ilmu kedokteran tak mampu memberikan solusi serta keinginan penderita maupun keluarga untuk dilibatkan secara langsung dalam proses pemilihan penyembuhan. Tujuan: Menentukan hubungan antara penggunaan Complementary and Alternative Medicine (CAM) dengan suku, pendidikan, agama, status ekonomi, status kesehatan dan usia. Metode: Desain penelitian ini adalah cross sectional study dengan populasi seluruh pasien pasien diabetes melitus yang berada di wilayah kerja Puskesmas Poasia Kota Kendari dengan jumlah sampel yang memenuhi kriteria sebesar 40 responden. Hasil: Penelitian ini menggambarkan bahwa tidak terdapat hubungan antara penggunaan CAM dan suku, pendidikan, agama, status ekonomi, status kesehatan, sedangkan terdapat adanya hubungan antara usia dengan penggunaan CAM. Simpulan: Masyarakat untuk dapat lebih aktif menemukan informasi mengenai perawatan kesehatan berdasarkan penggunaan CAM, serta peneliti dan institusi pendidikan untuk menggunakan terapi CAM sebagai bahan pembelajaran pada konsep terapi komplementer keperawatan.
\end{abstract}

Kata kunci: CAM, diabetes mellitus, komplementer, tradisional

\begin{abstract}
Public knowledge about the treatment of DM sufferers is inseparable from the suggestion of using herbal medicine compound therapy, which is often an alternative solution to the problem of medical science treatment unable to provide solutions, also the needs of diabetics to be directly involved in the treatment selection process. Objectives: To determined relationship between the use of CAM and ethnicity, education, religion, economic status, health status, and age. Methods: The study design was a cross-sectional study with a population of diabetes mellitus patients in the working area of the Poasia Health Center in Kendari City with a total sample of 40 respondents. Results: This study indicate there was no relationship between the use of CAM and ethnicity, education, religion, economic status, health status, while there is a relationship between the age and the use of CAM. Conclusions: The community to be able to more actively find information about health care about the use of CAM, and educational researchers to use CAM therapy as learning material on the concept of complementary nursing therapy
\end{abstract}

Keywords: CAM, complementary, diabetes mellitus, traditional

Affiliasi penulis: ${ }^{1}$ Departemen Keperawatan Medikal Bedah, Prodi DIII Keperawatan, Fakultas Sains dan Teknologi Universitas Sembilanbelas November Kolaka, Kolaka, Indonesia. ${ }^{2}$ Departemen Komunitas, Prodi Sarjana Keperawatan, Stikes Karya Kesehatan Kendari, Kendari, Indonesia.

Korespondensi: Risqi Wahyu Susanti, Email: risqi_wahyu@usn.ac.id Telp: 082347779759

\section{PENDAHULUAN}

Diabetes Melitus (DM) merupakan salah satu dari empat Noncommunicable Diseases (NCD) yang menjadi masalah kesehatan masyarakat penting saat ini. Prevalensi dan jumlah penderita DM selama beberapa dekade terakhir terus meningkat, sehingga 
ditargetkan untuk ditindaklanjuti oleh para pemimpin dunia. $^{1}$ Penderita DM seringkali mengalami permasalahan dalam perawatan penyakitnya seperti motivasi keluarga yang kurang dalam hal kontrol minum obat dan penyediaan makanan rendah kalori sebagai diit sehat DM serta kurang pengetahuan mengenai $\mathrm{DM}^{2}{ }^{2}$ Pengetahuan masyarakat mengenai pengobatan penderita DM tak lepas dari saran penggunaan terapi komplemeter obat herbal sebagai pengobatan turun temurun yang tidak jarang menjadi alternatif pemecahan masalah ketika ilmu kedokteran tak mampu memberikan solusi serta keinginan penderita maupun keluarga untuk dilibatkan secara langsung dalam proses pemilihan penyembuhan., Pemerintah Indonesia mulai menyarankan masyarakat menggunakan obat berbahan tradisional karena dinilai memiliki efek samping rendah diantaranya pengobatan diabetes melitus. ${ }^{5}$

Pada tahun 2014 sekitar 422 juta orang dewasa hidup dengan diabetes, sedangkan pada tahun 1980 terdapat hanya 108 juta yang dapat menyebabkan kematian sebesar 1,5 juta tahun 2012. Berdasarkan wawancara yang terdiagnosis dokter, prevalensi diabetes di Indonesia sebesar 1,5\%, ${ }^{6}$ Prevalensi diabetes melitus tahun 2016 di Sulawesi Tenggara sebesar 2.983 kasus. $^{7}$ Peningkatan jumlah penderita DM akan meningkatkan resiko komplikasi, termasuk stroke, kehilangan penglihatan, gagal ginjal, serangan jantung, amputasi kaki, dan kerusakan saraf sampai risiko kematian yang meningkat. ${ }^{1}$

Upaya untuk mengontrol diabetes melitus dan mencegah komplikasi dilakukan oleh tenaga kesehatan dengan intervensi dasar yang melibatkan obat-obatan, pendidikan dan konseling kesehatan, dan tindak lanjut yang konsisten. ${ }^{1}$ Pengobatan komplementer alternatif dinyatakan legalitasnya dalam UU No. 36 Tahun 2009 pasal 48: "Pelayanan kesehatan tradisional merupakan bagian dari penyelenggaraan upaya kesehatan" 8,9 Peraturan yang lebih lanjut mengatur penyelenggaraan pengobatan komplementer alternatif tertuang di dalam Permenkes no. 1109 tahun 2007 . $^{9}$

Penatalaksanaan CAM merupakan wewenang perawat yang tertuang dalam Undang-Undang Keperawatan Nomor 38 Tahun 2014, pada bab IV pasal 30 yang berbunyi: "Dalam menjalankan tugas sebagai pemberi Asuhan Keperawatan di bidang upaya kesehatan masyarakat, perawat berwenang: melakukan penatalaksanaan Keperawatan komplementer dan alternatif". ${ }^{10}$

Penggunaan CAM dapat memenuhi kebutuhan pasien diabetes melitus dalam hal efektivitas perawatan kesehatan yang diperoleh dari pengalaman, biaya murah dantersedia di komunitas pasien, serta sesuai dengan budaya dan gaya hidup dalam konteks komunitas ASEAN (Association of Southeast Asian Nations). ${ }^{11}$ Jenis CAM yang digunakan pada penderita diabetes melitus sangat beragam, diantaranya akupunktur, pijat, olahraga, herbal, terapi do'a, terapi berbasis diet, terapi bak mandi panas, biofeedback / relaksasi, dan menggunakan teknik manipulasi. ${ }^{11-14}$ Penggunaan terapi Complementary and Alternative Medicine (CAM) menunjukkan efek penurun glukosa dan diperkirakan $17 \%$ hingga $80 \%$ penggunaan diantara pasien diabetes mellitus. ${ }^{11}$

Faktor yang berhubungan dengan penggunaan CAM pada penelitian sebelumnya menyebutkan bahwa ras, usia, jenis kelamin, pendidikan, dan kondisi kesehatan fisik seperti nyeri merupakan faktor yang dapat mempengaruhi penggunaan CAM pada tiga penyakit kronis salah satunya diabetes melitus. ${ }^{12}$ Penelitian di Korea Selatan menyebutkan bahwa jenis kelamin, usia, status perkawinan, kekhawatiran akan kesehatan, dan kondisi penyakit kronik sangat berperan terhadap penggunaan CAM pada empat penyakit kronik yang salah satunya diabetes melitus. ${ }^{15}$

Berbagai penelitian tentang penggunaan CAM pada penderita diabetes melitus telah banyak dilakukan, namun penelitian mengenai faktor yang berhubungan dengan penggunaan CAM khususnya pada pasien diabetes melitus masih kurang dilakukan terutama di Indonesia sehingga peneliti tertarik meneliti hal tersebut khususnya di Kota Kendari.

\section{METODE}

Jenis penelitian ini adalah penelitian kuantitatif dengan desain penelitian adalah cross-sectional study yaitu studi dengan melibatkan pemeriksaan sekelompok subjek secara bersamaan dalam berbagai tahap perkembangan, tingkat pendidikan, tingkat keparahan penyakit, atau tahapan pemulihan untuk 
menggambarkan perubahan suatu fenomena di seluruh tahap, ${ }^{16}$ Variabel penelitian yaitu penggunaan CAM dan faktor-faktor yang berhubungan dengan penggunaan CAM pada pasien diabetes melitus dalam waktu yang bersamaan.

Populasi adalah kelompok individu atau elemen tertentu yang menjadi fokus penelitian. ${ }^{17}$ Populasi pada penelitian ini yaitu semua pasien diabetes melitus di wilayah kerja Puskesmas Poasia Kota Kendari, yaitu bulan januari sampai April 2018 adalah sebesar 343 penderita dengan rata-rata perbulan 86 penderita.

Sampel merupakan bagian dari populasi yang dipilih untuk penelitian tertentu, dan sampling mendefinisikan proses untuk memilih sekelompok orang, peristiwa, perilaku, atau elemen lain yang digunakan untuk melakukan penelitian. ${ }^{16}$ Teknik pengambilan sampel menggunakan simple random sampling yaitu dengan memilih secara acak elemen sampel dari kerangka sampling, peneliti dapat menulis nama pada secarik kertas, menempatkannya ke dalam wadah, mengacaknya, dan kemudian mengambil satu per satu hingga mencapai ukuran sampel yang diinginkan, metode yang paling umum untuk memilih subjek secara acak untuk studi adalah penggunaan program komputer. ${ }^{17}$

Sampel dalam penelitian ini adalah pasien diabetes melitus yang berada di wilayah kerja puskesmas Poasia Kota Kendari, pengambilan jumlah sampel berdasarkan tabel Jacob Cohen yaitu penentuan jumlah sampel untuk uji hubungan atau asosiasi dengan a 0.05 dengan estimasi power $80 \%$ adalah sebesar 66 orang sampel. ${ }^{18}$

Kriteria inklusi adalah; penderita diabetes mellitus dan bersedia menjadi responden. Kriteria Eksklusi adalah; kesulitan komunikasi dan mengalami retardasi mental. Sampel yang kemudian digunakan dalam penelitian setelah melalui kriteria inklusi dan eksklusi adalah sebanyak 40 responden.

Kuesioner penelitian ini terdiri dari tujuh bagian pertanyaan yang menyangkut penggunaan CAM disertai jenis-jenisnya dan faktor-faktor yang berhubungan dengan penggunaan CAM seperti suku, usia, pendidikan, agama, status ekonomi, dan kondisi kesehatan.
HASIL

Hasil penelitian mengenai faktor-faktor yang mempengaruhi penggunaan CAM pada penderita diabetes melitus di Wilayah Kerja Puskesmas Poasia adalah sebagai berikut.

Karakteristik penderita diabetes melitus yang menjadi responden di Wilayah Kerja Puskesmas Poasi adalah sebagai berikut:

Tabel 1. Karakteristik responden penderita diabetes melitus $(n=40)$

\begin{tabular}{|c|c|c|}
\hline Karakteristik & $f$ & $\%$ \\
\hline \multicolumn{3}{|l|}{ Suku } \\
\hline Tolaki & 7 & 17,5 \\
\hline Muna & 8 & 20,0 \\
\hline Bugis & 18 & 45,0 \\
\hline Jawa & 3 & 7,5 \\
\hline Makassar & 3 & 7,5 \\
\hline Menui & 1 & 2,5 \\
\hline Usia & \multicolumn{2}{|c|}{$53,58(31-75)^{*}$} \\
\hline \multicolumn{3}{|l|}{ Pendidikan } \\
\hline SD & 11 & 27,5 \\
\hline SMP & 6 & 15,0 \\
\hline SMA & 15 & 37,5 \\
\hline PT & 8 & 20,0 \\
\hline \multicolumn{3}{|l|}{ Agama } \\
\hline Islam & 38 & 95,0 \\
\hline Kristen & 2 & 5,0 \\
\hline \multicolumn{3}{|l|}{ Status Ekonomi } \\
\hline Tinggi & 5 & 12,5 \\
\hline Menengah & 10 & 25,0 \\
\hline Rendah & 25 & 62,5 \\
\hline Kondisi Kesehatan & \multicolumn{2}{|c|}{$7,70(6-10)^{*}$} \\
\hline \multicolumn{3}{|l|}{ Penggunaan CAM } \\
\hline Tidak Menggunakan & 1 & 2,5 \\
\hline Menggunakan 1-3 & 24 & 60,0 \\
\hline Menggunakan $>3$ & 15 & 37,5 \\
\hline
\end{tabular}

Ket *Mean(min-max)

Sumber: Data Primer 2019

Berdasarkan tabel di atas, suku yang paling dominan menderita diabetes melitus adalah suku Bugis yaitu dengan jumlah 18 orang (45\%), sedangkan rata-rata usia penderita adalah 54 tahun, dengan tingkat pendidikan terakhir adalah SMA sebesar 15 orang (37,5\%), agama dominan adalah agama Islam dengan jumlah 38 orang (95\%), adapun status ekonomi yang paling banyak adalah status ekonomi rendah dengan jumlah 25 orang (62,5\%), 
dengan kondisi kesehatan rata-rata berada dalam rentang kurang baik $(7,70)$, dan rata-rata menggunakan CAM 1-3 berjumlah 24 orang (60\%).

Data yang didapatkan dari 40 responden terdapat 26 orang menderita penyakit selain hipertensi dan terdapat 7 responden yang menderita lebih dari satu penyakit penyerta. Berikut ini daftar penyakit yang diderita oleh responden.

Tabel 2. Jenis penyakit penyerta responden

\begin{tabular}{lc}
\hline & Jumlah \\
\hline Hipertensi & 22 \\
Penyakit jantung (CHF, Angina Pectoris) & 4 \\
Penyakit GI (gastritis \& dispepsia) & 3 \\
Gastritis & 2 \\
Gagal Ginjal & 1 \\
Ca mamae & 1 \\
Stroke & 1 \\
Luka DM & 1 \\
Hiperuremia & 1 \\
Anemia Gravis & 1 \\
\hline
\end{tabular}

Sumber: Data Sekunder 2019

Berdasarkan data di atas, ditemukan bahwa penyakit Hipertensi merupakan penyakit terbanyak yang menyertai penyakit diabetes melitus dengan jumlah 22 responden.

Adapun jenis CAM yang digunakan oleh responden adalah sebagai berikut.

Tabel 3. Jenis CAM yang digunakan oleh responden

\begin{tabular}{lc}
\hline Jenis CAM & Jumlah \\
\hline Sholat sunnah & 7 \\
Dzikir & 14 \\
Berdo'a & 11 \\
Senam & 9 \\
Jalan Kaki & 17 \\
Bersepeda & 1 \\
Joging & 2 \\
Herbal Kayu Manis & 5 \\
Herbal Daun Salam & 4 \\
Herbal Lain & 27 \\
\hline
\end{tabular}

Sumber : Data Primer 2019

Faktor-faktor yang berhubungan dengan penggunaan CAM di Puskesmas Poasia dapat dilihat pada tabel berikut ini.
Tabel 4. Hasil analisis faktor-faktor yang mempengaruhi penggunaan CAM

\begin{tabular}{|c|c|c|c|c|c|}
\hline \multirow[b]{2}{*}{ Variabel } & \multicolumn{3}{|c|}{ Penggunaan CAM } & \multirow[b]{2}{*}{ p } & \multirow[b]{2}{*}{$r$} \\
\hline & $\begin{array}{l}\text { Tidak } \\
\text { meng } \\
\text { gunak } \\
\text { an }\end{array}$ & $\begin{array}{l}\text { Menggu } \\
\text { nakan } \\
1-3\end{array}$ & $\begin{array}{l}\text { Meng } \\
\text { gunak } \\
\text { an > } 3\end{array}$ & & \\
\hline Suku & & & & $1,000+$ & 0,000 \\
\hline Tolaki & 0 & 4 & 3 & & \\
\hline Muna & 0 & 4 & 3 & & \\
\hline Bugis & 0 & 11 & 7 & & \\
\hline Jawa & 0 & 2 & 1 & & \\
\hline Makassar & 1 & 1 & 1 & & \\
\hline Menui & 0 & 1 & 0 & & \\
\hline Usia & & & & $0,001 \#$ & 0,5 \\
\hline Pendidikan & & & & $0,752^{*}$ & $-0,035$ \\
\hline SD & 0 & 7 & 4 & & \\
\hline SMP & 0 & 5 & 1 & & \\
\hline SMA & 1 & 5 & 9 & & \\
\hline PT & 0 & 7 & 1 & & \\
\hline Agama & & & & $0,289+$ & 0,032 \\
\hline Islam & 1 & 22 & 15 & & \\
\hline Kristen & 0 & 2 & 0 & & \\
\hline Status & & & & $0,601^{*}$ & 0,075 \\
\hline \multicolumn{6}{|l|}{ Ekonomi } \\
\hline Tinggi & 0 & 3 & 2 & & \\
\hline Menengah & 1 & 6 & 3 & & \\
\hline Rendah & 0 & 15 & 10 & & \\
\hline Status & & & & $0,798 \#$ & $-0,042$ \\
\hline kesehatan & & & & & \\
\hline
\end{tabular}

Berdasarkan tabel di atas, yang telah dilakukan analisis menggunakan bantuan komperisasi didapatkan hasil bahwa hanya usia yang berhubungan dengan penggunaan CAM yaitu dengan nilai $p<0,05$, dengan kekuatan hubungan besar $(0,5)$. Sedangkan Suku tidak berhubungan dengan penggunaan CAM dengan nilai $p=1,000$, pendidikan juga tidak berhubungan dengan penggunaan CAM dengan $\mathrm{p}=0,752$, faktor agama juga tidak berhubungan dengan penggunaan CAM dengan $p=0,289$, faktor status ekonomi juga tidak berhubungan dengan penggunaan CAM dengan $p=0,601$ dan faktor status kesehatan juga tidak berhubungan dengan penggunaan CAM dengan $p=0,798$. 


\section{PEMBAHASAN}

\section{Suku dan penggunaan CAM}

Hasil penelitian saat ini menujukkan bahwa, tidak ada hubungan suku dengan penggunaan CAM pada pasien diabetes melitus. Hal tersebut dibuktikan dengan hasil uji statistik $\rho=1,000$. Selanjutnya dibuktikan dengan tidak meratanya penggunaan CAM. Untuk suku bugis, 11 responden menggunakan $1-3$ CAM sedangkan 7 responden menggunakan lebih dari 3 CAM.

Suku Tolaki dan Muna, masing - masing empat responden menggunakan 1 - 3 CAM sedangkan tiga responden menggunakan lebih dari 3 CAM. Nilai $r$ diperoleh, 0,000. Hal tersebut berarti kekuatan hubungan adalah lemah.

Tidak adanya hubungan tersebut mungkin dikarenakan penggunaan obat atau terapi komplementer dan alternatif dalam mengobati diabetes melitus tidak sesuai dengan tradisi dalam suku dan kebudayaan. Responden juga beranggapan bahwa obat atau terapi komplementer dan alternatif tidak sepenuhnya diyakini dapat menyembuhkan diabetes melitus sesuai dengan tradisi yang dianut dalam suku dan kebudayaan responden.

Pengobatan komplementer mengacu pada sekelompok disiplin terapeutik dan diagnostik yang ada di luar lembaga di mana perawatan kesehatan konvensional diajarkan dan diberikan. ${ }^{19}$ CAM adalah yang umumnya tidak dianggap sebagai bagian dari pengobatan konvensional seperti kelompok beragam praktik, produk, serta sistem perawatan medis dan kesehatan.$^{20}$ Obat konvensional digunakan bersama dengan obat komplementer, dan pengobatan alternatif digunakan di tempat pengobatan konvensional. ${ }^{20}$

\section{Usia dan penggunaan CAM}

Hasil penelitian saat ini menujukkan bahwa usia dapat dihubungkan dengan penggunaan CAM pada pasien diabetes melitus. Hal tersebut dibuktikan dengan hasil uji statistik $\rho=0,001$. Rerata usia responden penderita DM adalah 53,58 tahun. Hasil penelitian tersebut tidak jauh berbeda dengan hasil penelitian yang diacu oleh Limbong et al (2015), dari 31 responden $93,5 \%$ berusia antara $40-65$ tahun. ${ }^{21}$
Studi yang lain juga mengungkapkan bahwa kelompok usia memiliki risiko DM tipe 2 yang lebih tinggi karena perubahan menurunnya kemampuan kompensasi sel beta pankreas dalam menghadapi resistensi insulin, aktivitas fisik, dan proses metabolisme lemak. $^{22}$ Tidak adanya hubungan tersebut dikarenakan penggunaan CAM tidak mengacu pada usia penderita DM. Namun, lebih cenderung dipengaruhi oleh upaya mencari alternatif pengobatan DM. Hal tersebut dilakukan dengan harapan kadar gula darah dapat terkontrol.

Hasil penelitian lain juga menunjukkan rata-rata usia responden 62,7 tahun. ${ }^{23}$ Disamping faktor riwayat keluarga dan obesitas, salah satu faktor resiko terhadap peningkatan jumlah pasien DM adalah usia diatas 45 tahun. perubahan anatomis, fisiologis dan biokimia menyebabkan proses penuaan yang dapat menimbulkan gangguan sel beta dan menurunkan sensitivitas insulin sehingga pada usia lanjut memiliki produksi insulin yang berkurang. ${ }^{23}$

\section{Pendidikan dan penggunaan CAM}

Hasil penelitian saat ini menunjukkan bahwa, pendidikan tidak ada hubungannya dengan penggunaan CAM pada pasien diabetes melitus. Hal tersebut dibuktikan dengan hasil uji statistik $\rho=0,752$. Tidak adanya hubungan pendidikan dengan penggunaan CAM pada pasien diabetes melitus disebabkan karena semakin rendah pendidikan sesorang semakin buruk juga pencegahannya terhadap diabetes melitus.

Pasein DM harus memiliki pendidikan yang baik, disebabkan pendidikan menjadi bagian indikator pada pemahaman pasien mengenai perawatan, pengontrolan kadar glukosa, dan penatalaksanaan diri. Perilaku positif dihasilkan oleh Pendidikan yang baik sehingga lebih obyektif dan terbuka dalam menerima informasi, yaitu informasi tentang penatalaksanaan $\mathrm{DM}^{23}$ Informasi kesehatan yang diterima secara terbuka oleh pasien DM dapat menjadi pedoman pasien untuk aktif dalam melakukan aktivitas self-care dan dapat terkendalinya kadar glukosa darah serta tetap stabilnya status kesehatan pasien. ${ }^{23}$ 
Pendidikan yang telah di capai erat hubungannya dengan pengetahuan seseorang. Pengetahuan tentang kesehatan tidak begitu mendalam pada orangorang yang memiliki tingkat pendidikan rendah. Hal ini bisa menjadi penyebab tidak mendalamnya pengetahuan mereka mengenai penyakit Diabetes Melitus. $^{24}$

\section{Agama dan penggunaan CAM}

Hasil penelitian saat ini menujukkan bahwa, tidak ada hubungan agama dengan penggunaan CAM pada pasien diabetes melitus. Hal tersebut dibuktikan dengan hasil uji statistik $\rho=0,289$. Tidak adanya hubungan agama dengan penggunaan CAM, kemungkinan disebabkan oleh karena terapi CAM tidaklah monoton dilakukan oleh penganut agama tertentu. Hal ini sesuai dengan penelitian yang menunjukkan bahwa pengobatan tradisional atau komplmenter tiddak dipengaruhi oleh variabel agama atau kepercayaan. ${ }^{25}$

\section{Status ekonomi dan penggunaan CAM}

Hasil penelitian saat ini menujukkan bahwa, tidak ada hubungan status ekonomi dengan penggunaan CAM pada pasien diabetes melitus. Hal tersebut dibuktikan dengan hasil uji statistik $\rho=0,601$. Studi lainnya menegaskan bahwa bila status sosial ekonomi akan meningkat jika memiliki penghasilan yang besar, yang akan meningkatkan kemampuan pasien DM lebih baik dalam melakukan pemantauan metabolik. ${ }^{23}$

Self-care pasien DM dapat dipengaruhi oleh biaya pengobatan yang dikeluarkan, secara signifikan pasien dapat melakukan pemeriksaan gula darah secara teratur setidaknya dua kali seminggu jika memiliki masalah keuangan yang tidak besar. Sebuah studi juga mengungkapkan bahwa perubahan sosial ekonomi dan pergeseran gaya hidup di Indonesia khususnya di Sulawesi Utara, perbaikan atau peningkatan di sektor pendapatan (ekonomi) dapat merubah gaya hidup seperti konsumsi makanan, promosi makanan trendy ala barat, utamanya fast food, dan kesibukan kerja yang tinggi yang tidak diimbangi dengan kesadaran gizi danpengetahuan. ${ }^{26}$ Hal tersebut menyebabkan budaya makan menjadi lebih ke arah konsumsi tinggi gula dan lemak jenuh, rendah zat gizi mikro dan rendah serat, yang akan menimbulkan masalah obesitas, gizi lebih, dan meningkatkan radikal bebas yang akhirnya memicu munculnya penyakit degeneratif khususnya Diabetes Melitus tipe 2 dan menyebabkan perubahan pola penyakit. $^{28}$

\section{Status kesehatan dan penggunaan CAM}

Hasil penelitian saat ini menujukkan bahwa, tidak ada hubungan status kesehatan dengan penggunaan CAM pada pasien diabetes melitus. Hal tersebut dibuktikan dengan hasil uji statistik $\rho=0,789$. Tidak mudah untuk mendapatkan kualitas hidup yang baik pada penderita DM. Perbaikan status kesehatan memiliki hubungan dengan kualitas hidup pada penderita DM. Diet ketat sehari-hari harus dijalani oleh penderita untuk menormalkan kadar glukosa darah. Seseorang yang memiliki kesehatan secara fisik, psikologis, dan mampu melaksanakan aktifitasnya sehari-hari akan dikatakan memiliki kualitas hidup yang baik. ${ }^{27}$

Diabetes Melitus tipe 2 adalah penyakit multifaktorial yang memiliki komponen genetik dan lingkungan yang berkontribusi sama kuatnya pada proses munculnya penyakit tersebut. Sebagian dari faktor ini bisa dimodifikasi dengan perubahan gaya hidup, dan beberapa faktor lainnya tidak dapat diubah. ${ }^{24}$ Pasien DM yang memiliki kesadaran diri yang baik akan mengetahui segala hal tentang penyakit dan dirinya dengan baik. Sehingga dengan demikian, akan mampu menerima keadaan dirinya dan berpartisip asi aktif dalam menangani masalah kesehatan. ${ }^{28}$

\section{SIMPULAN}

Penggunaan CAM tidak ada hubungannya dengan suku, pendidikan, agama, status ekonomi, status kesehatan, sedangkan dijumpai adanya hubungan antara usia dengan penggunaan CAM.

\section{SARAN}

Masyarakat untuk dapat lebih aktif menemukan informasi mengenai perawatan kesehatan berdasarkan penggunaan CAM serta peneliti dan institusi pendidikan untuk menggunakan terapi CAM sebagai bahan pembelajaran pada konsep terapi komplementer keperawatan. 


\section{UCAPAN TERIMA KASIH}

Terimakasih kepada semua pihak yang memberikan kontribusi terhadap penelitian ini terutama pihak dan staf Puskesmas Poasia yang telah memberikan izin untuk terlaksananya penelitian ini.

\section{DAFTAR PUSTAKA}

1. World Health Organization (WHO). Global report on diabetes. WHO Library Cataloguing [serial online]. 2016 (diunduh 22 Agustus 2019). Tersedia dari: http://www.who.int

2. Raditiya B, Aditya M. Penatalaksanaan diabetes melitus tipe 2 dengan hiperkolesterolemia pada seorang pria usia 60 tahun dengan pendekatan kedokteran keluarga. J Medula Unila. 2016;5(2):9-17.

3. Satria D. Complementary and alternative medicine (cam): fakta atau janji? Idea Nurs J. 2013;4(3):82-90.

4. Widyastuti. Terapi komplementer dalam keperawatan. J Keperawatan Indones. 2008; 12 (1):53-7.

5. Leonita E, Muliani A. Penggunaan obat tradisional oleh penderita diabetes mellitus dan faktor-faktor yang berhubungan di wilayah kerja Puskesmas Rejosari Pekanbaru tahun 2015. J Kesehat Komunitas. 2015;3(1):47-52.

6. Kementerian Kesehatan RI. Riset kesehatan dasar. Jakarta; 2013. (diunduh 5 November 2017). Tersedia dari: http://dinkes.bantenprov.go.id/upload/article doc/ Hasil Riskesdas 2013.pdf

7. Dinas Kesehatan Sulawesi Tenggara. Profil kesehatan Provinsi Sulawesi Tenggara. Kendari: Data \& Informasi Dinas Kesehatan Provinsi Sulawesi Tenggara; 2017. (diunduh 3 April 2018). Tersedia dari: http://www.depkes.go.id/ resources/download/profil/PROFIL KES PROVI NSI 2016/28 Sultra 2016.pdf?opwvc=1

8. Undang-Undang Republik Indonesia Nomor 36 Tentang Kesehatan. Jakarta; 2009.

9. Erry, Susyanty AL, Sasanti R. Kajian implementasi kebijakan pengobatan komplementer alternatif dan dampaknya terhadap perijinan tenaga kesehatan praktek pengobatan komplementer alternatif akupuntur.
Bul Penelit Sist Kesehat. 2014;17(3):275-84.

10. Undang - Undang Republik Indonesia nomor 38 tahun 2014 tentang keperawatan. Jakarta; 2014. (diunduh 12 Desember 2014). Tersedia dari: http://silemkerma.dikti.go.id//assets/panduan/UU 382014 Keperawatan.pdf

11. Matheka M, Alkizim FO. Complementary and alternative medicine for type 2 diabetes mellitus: Role of medicinal herbs. J Diabetes Endocrinol. 2012;3(4):44-56.

12. Ndao-Brumblay SK, Green CR. Predictors of complementary and alternative medicine use in chronic pain patients. Pain Med. 2010;11(1):1624.

13. Jones RA, Utz S, Wenzel J, Steeves R, Hinton I, Andrews $\mathrm{D}$, et al. Use of complementary and alternative therapies by rural African Americans with type 2 diabetes. Altern Ther Health Med. 2006;12(5):34.

14. Pumthong $G$, Nathason $A$, Tuseewan $M$, Pinthong P, Klangprapun S, Thepsuriyanon D, et al. Complementary and alternative medicines for diabetes mellitus management in ASEAN countries. Complement Ther Med. 2015;23(4): 617-25.

15. Choi B, Han D, Na S, Lim B. Factors related to the parallel use of complementary and alternative medicine with conventional medicine among patients with chronic conditions in South Korea. Integr Med Res. 2017;6(2):223-9.

16. Grove SK, Burns N, Gray J. The practice of nursing research: Appraisal, synthesis, and generation of evidence. St. Louis Missouri: Elsevier Saunders; 2013.

17. Grove SK, Gray JR, Burns N. Understanding nursing research: Building an evidence-based practice. St. Louis Missouri: Saunders Elsevier; 2015.

18. Rubin A. Statistics for evidence-based practice and evaluation. Belmont: Brooks Cole; 2010.

19. Zollman C, Vickers A, Richardson J. ABC of complementary medicine. 2th Ed. India: Blackwell; 2008.

20. NCCAM. The Use of Complementary and Alternative Medicine in the United States. 2017 (diunduh 10 Maret 2018). Tersedia dari: 
https://nccih.nih.gov/research/statistics/2007/cam survey fs1.htm

21. Limbong $\mathrm{M}$, Jaya $\mathrm{RD}$, Ariani $\mathrm{Y}$. Pengaruh relaksasi autogenik terhadap kadar gula darah pada pasien diabetes melitus tipe 2 di Puskesmas Pancoran Mas Depok. J Sk Keperawatan. 2015;1(1):21-8.

22. Harsari $\mathrm{RH}$, Fatmaningrum $\mathrm{W}$, Prayitno $\mathrm{JH}$. Hubungan status gizi dan kadar glukosa darah pada pasien diabetes melitus tipe 2. eJournal Kedokt Indones. 2018;6(2):2-6.

23. Rantung J, Yetti K, Herawati T. Hubungan selfcare dengan kualitas hidup pasien diabetes mellitus (DM) di persatuan diabetes Indonesia (Persadia) Cabang Cimahi. J Sk Keperawatan. 2015;1(01):38-51.

24. Mongisidi G. Hubungan antara status sosioekonomi dengan kejadian diabetes melitus tipe 2 di poliklinik interna BLU RSUP Prof. Dr. R. D.
Kandou. Fak Kesehat Masy Univ Sam Ratulangi. 2014;5(1):72-84.

25. Ervina L, Ayubi D. Peran kepercayaan terhadap penggunaan pengobatan tradisional pada penderita hipertensi di Kota Bengkulu. Perilaku dan Promosi Kesehat. 2018;1(1):1-9.

26. Kusno FA, Kapantow NH, Ratag BT. Hubungan antara status sosial ekonomi dengan kejadian diabetes melitus tipe 2 di poliklinik interna rumah sakit umum daerah (RSUD) Bitung tahun 2015. Media Kesehat. 2015;7(4):5-6.

27. Purwandari H, Susanti SN. Hubungan kepatuhan diet dengan kualitas hidup pada penderita DM di poli penyakit dalam RSUD Kertosono. Str J IIm Kesehat. 2017;6(2):16-21.

28. Rikanurrizki, Mudatsir, Mulyadi. Penyuluhan kesehatan dengan SMS terhadap kesadaran diri pada anggota keluarga dengan diabetes mellitus di poli endokrin RSUDZA. J IImu Keperawatan. 2017;5(1):73-84. 